\title{
A systematic review of treatment attrition in anorexia nervosa
}

\author{
Ghafda Abdelbaky ${ }^{1 *}$, Philipa Hay ${ }^{2}$, Stephen Touyz ${ }^{3}$ \\ From 2013 ANZAED Conference: Inspiring Change: Person and Context \\ Melbourne, Australia. 23-24 August 2013
}

\section{Background}

Understanding of reasons for attrition in anorexia nervosa therapy is incomplete.

\section{Aims}

This systematic review was of trials that reported factors associated with attrition, and aimed to compare and contrast findings between treatment settings.

\section{Methods}

Data were extracted from published reports sourced from searches (dates to 2/2013) of SCOPUS, PubMED, PsycINFO, included French and English language papers, and search terms: 'anorexia nervosa' and 'attrition /dropout/premature termination of treatment/outcome'.

\section{Results}

421 papers were identified, 34 met inclusion criteria, 4 were excluded as they were reviews, and 3 investigated outcome not attrition. Two papers of the 27 included were qualitative studies. Factors consistently associated with attrition in any treatment setting were the type of anorexia nervosa, where the purging type was associated with higher attrition rate than the restrictive type, and poor motivation to change. Less consistent findings were reported in regards to co-morbidity and personality features. The majority of trials were of adults or older adolescents, and over $70 \%$ were of inpatient samples.

\section{Conclusion}

More studies of attrition in younger people and outpatient settings, and more consistent and standardised

\footnotetext{
* Correspondence: aisha25@hotmail.com

${ }^{1}$ Institute of Psychiatry Fellow, School of Medicine, University of Western Sydney, Australia

Full list of author information is available at the end of the article
}

assessment of co-morbidity and personality in anorexia nervosa research is needed. Expanding motivational enhancement strategies in therapy may reduce attrition.

\section{Authors' details \\ ${ }^{1}$ Institute of Psychiatry Fellow, School of Medicine, University of Western Sydney, Australia. ${ }^{2}$ School of Medicine, University of Western Sydney, Australia. ${ }^{3}$ School of Psychology and Centre for Eating and Dieting Disorders} (Boden Institute), University of Sydney, Australia.

Published: 14 November 2013

doi:10.1186/2050-2974-1-S1-P1

Cite this article as: Abdelbaky et al:: A systematic review of treatment attrition in anorexia nervosa. Journal of Eating Disorders 2013 1(Suppl 1): P1.
Submit your next manuscript to BioMed Central and take full advantage of:

- Convenient online submission

- Thorough peer review

- No space constraints or color figure charges

- Immediate publication on acceptance

- Inclusion in PubMed, CAS, Scopus and Google Scholar

- Research which is freely available for redistribution

Submit your manuscript at www.biomedcentral.com/submit
C Biomed Central

\section{(Ciomed Central}

